Bol. Acad. peru. leng. 50. 2010 (183-189)

\title{
LENGUAJE Y SURREALISMO
}

\author{
Luis Jaime Cisneros \\ Academia Peruana de la Lengua
}

Fecha de recepción:

$02 / 10 / 2010$

Fecha de aceptación:

$30 / 10 / 2010$

Con un desprecio casi ritual por el lenguaje de los gramáticos, los surrealistas aceptaron esta afirmación de Bonterapelli, que lucía, entre 1926-27, en el segundo número de la revista 900:

"Nunca discutiremos en cuestiones de lenguaje; cuestiones ociosas y absurdas, puesto que un idioma jamás existe por sí mismo y carece de importancia en sí; sólo importan el pensamiento y la imaginación"

Cuando Bretón definía el movimiento, anunciaba así sus objetivos: se trata de expresar, a través de un automatismo psíquico puro, "el funcionamiento real del pensamiento", al margen de toda preocupación estética o moral. Sin contacto alguno con la razón. Libertad absoluta de lo imaginario, en suma. Si estudiamos la repercusión de estas afirmaciones en el plano del lenguaje, observamos que las palabras son como una manera "de dividir, objetivar y coordinar la realidad". En resumen: una palabra "nunca significa escuetamente su objeto: siempre la tensión vital entre el 
sujeto y el objeto". ¿Qué significa esta afirmación? Una significación es siempre leemos en Amado Alonso- "una visión interesada del objeto". Esto significa que cuando se desplazan los centros de nuestro interés, el sistema léxico se va dislocando y reorganizando según el nuevo sentido íntimo". Esto ocurre en el lenguaje de los surrealistas cuando se les hace evidente la necesidad de que lo pensable tenga prioridad sobre el pensamiento. Como dice Hatzfeld:

"[...] el lenguaje imaginativo sirve al hechizo unanímista cuando sugiere superconcreción en el mundo de las ideas y acción consciente en el reino de los objetos inanimados" (El superrealismo, 136)

Se trata de transformar la vida en una superrealidad, y eso conduce lógicamente (es Hatzfeld quien lo dice, 140) "a un lenguaje mítico y altamente metafórico en el cual la vida y su mito correspondiente se unen". Como la imaginación tiene acá gran importancia, las palabras que van a interesarnos son las que servirán al poeta para traducir imágenes. Gastón Bachelard afirma que aquí "le langage est aux postes de comnande de l'imagination". ${ }^{1}$

Y afirma en otro lugar (Eau) que "lo irreal comanda el realismo de la imaginación”. Pero esta imagen no está destinada al halago de la contemplación: debe actuar, debe estar dotada de fuerza. Es una imagen fuerte, poderosa y actuante.

En este lenguaje poético se va abriendo camino el mundo interior de los sueños, que constituyen el triunfo de la imagen autónoma y de sus incoherentes y libres asociaciones. Lo vago e indeciso adquiere la fisonomía, el perfil y la resonancia de lo concreto y de lo real. Los estados de ánimo se confunden con los objetos y actúan como tales. El lenguaje se va transfigurando para servir de expresión. Es la época del célebre libro de Bergson, Essai sur les données inmédiats de la conscicnce, donde podemos leer: "La palabra de contornos bien precisos, la palabra

$1 \quad$ La terre et les reveries de la volonté: essai sur l'imagination, 1948, pág. 8 
brutal, almacena cuánto hay de estable, de común y por consecuencia de impersonal en las impresiones delicadas y fugitivas de nuestra conciencia individual", 99.

Leamos estos textos de Vicente Aleixandre, en prosa, y en verso, como testimonio de este nuevo manejo de palabras:

Alardeo de barbas fiscas y entremezclando mis dedos y mis rencores evoco el vino rojo que acabo de dejar sobre las pupilas dormidas de una muchacha. $\mathrm{He}$ aprovechado su sueño para escaparme de puntillas, presumiendo que la madrugada sería herbosa como un sueño desollado con jaspes, veteado de ágatas transitorias. (“El solitario”, en Poesía surrealista, Barcelona, 1971, 40)

Entrar sin música en el mar; vengo del mundo, del mundo o del agotamiento. No pido espinas ni firmezas; arenas, ignoradme. Vengo soltando música por los talones verdes; algas del mar, no agitéis vuestros odios. ("Playa ignorante", ibid., 60).

Se trata, pues, de que en esta operación lingüística participen conjuntamente los sentidos, la razón y los sentimientos, al unísono. Lo dice elocuentemente este fragmento del peruano César Moro:

Tus hijos fueron azules y ponías manzanas moradas en cestos de mimbre desbordantes de paños blancos las uvas soñaban juntas a las sardinas y los platos blancos y azules tus naturalezas muertas ven pasar en la noche que iluminan la carrera furtiva de los ratones académicos diabólicos aquella mujer verde y violeta en una bailadera de jade falso deja escurrir un agua incomparable que bien podía figurar el coro de los pintores contemporáneos si fueran tan inteligentes como el perro.

(Homenaje a Bonnard)

No importa que esto choque violentamente con la lógica: interesa que no choque con la imaginación. Hay que pensar con imágenes. Hay que proponer sentido con imágenes. En este lenguaje poético tiene singular 
relieve el adjetivo, que aparece unido de modo inusual para ofrecernos una imagen "cualitativa 'incoherente' respecto de la significación real" del sustantivo al que modifica. Es decir, una incoherencia. Una incoherencia solamente posible en el ámbito de la imaginación, sólo imaginable, 'nunca real'. Es esa incoherencia la que favorece el choque entre los elementos asociados en el sintagma. Valéry decía que siempre había una palabra para aludir a las cosas no oscurecidas por el hombre. La aspereza originada al combinar dos elementos de realidad tan distinta constituye, para el creador francés de esta costumbre lingüística, "la luz de la imagen". En el español Vicente Aleixandre encontramos varios ejemplos: "Vengo soltando música por los talones verdes". Talones verdes. Juzgado con anteojos lógicos, imposibilidad real. Imaginariamente posible: puedo soñar con talones verdes. Los puedo imaginar. Evidentemente, los puedo pintar. Es decir, lo que hasta aquí era gramaticalmente imposible, asociar la realidad 'talón' (sustantivo) a la realidad 'verde' (adjetivo), se hace ahora lingüísticamente posible. Asocio ambos significados más allá de esta realidad en que los demás los concretizan y los invento y les doy vida en otra dimensión, ¿también real? Estoy, así, frente a una posibilidad suprarreal. Y gracias a esta audacia, puedo atribuir a los objetos cualidades insospechadas. A los objetos y a las personas. Revoluciono, así, el mundo de lo animado y de lo inanimado. El derecho de imaginar me facilita el acceso a esos campos que quiebran el límite de lo real. Por eso, en el campo linguístico, la asociación sustantivo-adjetivo acusa los primeros síntomas de esta moda literaria.

¿Qué trascendencia le asignamos a todo esto? Mucha. A medida que voy atribuyendo a las cosas cualidades ajenas a ellas y a la realidad en que tienen asegurada esencia, las mismas cosas aparecen transformadas, irreconocibles, distintas. Es decir, son otras. De este modo, nuestra perspectiva de significación se amplía, adquiere mayor horizonte y favorece nuevas asociaciones y origina también nuevas familias semánticas. Con solo desordenar la normal relación habitual entre las cosas y sus cualidades inherentes, extiendo hacia el infinito el instrumental retórico que estaba a nuestra disposición. Aquí nos lo muestra este lúcido ejemplo de García Lorca: 
El aullido

es una larga lengua mora di que deja

hormigas de espanto y licor de lirios.

Aquí tenemos la percepción cromática de un fenómeno auditivo. Las calificaciones comportan habitualmente una senestesia. No se trata, como en el lenguaje modernista, de una sensibilidad subjetiva que va insinuando y repartiendo 'matices'. Se trata de otra cosa: asistimos a una "violenta voluntad de creación". La cualidad con que los objetos vienen revestidos no aparece como fruto de una atribución del hablante, como algo accidental, ni como el resultado de una impresión. Es lo que ve el creador: él inventa esa cualidad, la ve y la siente como 'insustituible'. Así como insustituible aparece la calificación que lucen los versos de Aleixandre:

Mientras suenan campanas como zapatos tibios.

Este ejercicio de adjetivación puede llevar (como explicó Borges, años atrás) a la simulación del adjetivo, a "un sistema premeditado de epítetos balbucientes y adjetivos tahúres". Al analizar este cuarteto del uruguayo Herrera y Reissig:

Quimérica a mi vera concertaba tu busto albar su delgadez de ondina con mística quietud de ave marina en una acuñación escandinava

Borges adelanta esta explicación:

Herrera y Reissig, para definir a su novia (más valdría poner: para indefinirla), ha recurrido a los atributos de la quimera, trinidad de león, de sierpe y de cabra, a los de las ondinas, al misticismo de las gaviotas y los albatros, y, finalmente, a las acuñaciones escandinavas, que no se sabe lo qué serán. (El tamaño de la esperanza. 1926, 55) 
Otro ejemplo elocuente nos lo ofrece el siguiente pasaje de Aleixandre:

"que un párpado de espuma respira quietamente pero que nunca accederá a dormir en nuestro seno"

Vale la pena detenernos y analizar el pasaje, 'párpado de espuma' es lo primero por considerar. Cuando nos salta el primer significado de párpado nos lo desdibuja el determinativo de 'espuma', incapaz de convocarnos a la realidad; de modo que, al precisarlo, nos lo arrebata de 'esta realidad concreta' y lo instala en la de más allá. En seguida viene lo grave. De este párpado de espuma se dice que respira, que es, en la realidad, el modo 'visual' de aludir al abrir y cerrar el párpado normal. Y cuando vamos haciéndonos cargo de tales dificultades de asociación y arriesgamos la imagen, el adverbio se anuncia para modificar el significado habitual del verbo al aclarararnos que 'respira quietamente' (con quietud). La realidad acaba de ser desrrealizada, pero tiene ahora entidad, y viva, en una nueva dimensión del sentido. Y es que estamos ante una nueva concepción del lenguaje artístico. En general, "el lenguaje artístico crea utilizando la palabra en asociaciones insólitas". Lo proclama Boris Toraacheski en su Teoría de la literatura, de 1928:

"El lenguaje artístico da la impresión de cierta novedad en el uso de las palabras y resulta así una especie de neoformación".

Podemos comprobarlo en la siguiente lectura de Lezama Lima:

"La preste y la luz encaramadas como una gata rodeando la mazmorra" (Bajorrelieve)

Y es que en la base del léxico poético debemos reconocer la renovación de las palabras. Y tal renovación puede lograrse "trasladando la palabra a un ámbito lexicográfico insólito, o atribuyéndole un significado insólito".2

Eficazmente puede ilustrarse en el soneto "Leitmotiv" de Martín Adán: 
No aquel Chopin de la melografía:

Colibrí infalible en vahaje,

O cumbrera y cabrío nel celaje, perspicuo piloto por sombría...

-Mas el antiscio de su travesía:

Arena así, que ya brolla el miraje;

O humana presa de selacio aguaje

O luna aguada, o flor de mediodía.

-No la remera que roza la rosa,

Sino el otoño que bañó mi vida,

y pasmó mi melisma más mimosa

¡Ay, no la arboladura talantossa,

$\mathrm{Ni}$ el alentar la luna rehenchida!...

¡Mas ya ... ya ... mudo que trajo la broza!

Varios pueden ser los procedimientos. Para que la expresión alcance relieve, si nos acogemos a las ideas de Tomacheski. Basta con incorporar al discurso "palabras extraídas de un ámbito lexicográfico distinto" porque, de ese modo, al descubrirlas en un contexto ajeno, "estas palabras "polarizarán la atención". Tal vez podamos comprobarlo en este pasaje del colombiano León de Greiff (Relato de Gunnar Tromholt);

Oh, fulvo río Ñus, ululante, roqueño.

Oh río en el que el ojo clava su ardiente jade:

' del tren al caligíneo hervor- al ser transido

frente de tí, tu dalvajez invade,

Oh río en el que el ojo clava su ardiente palpo, túrbido Ñus, cuando la tarde hosca fenece:

-del tren al caligíneo hervor- el ser atónito

frente a su salvajez se alea y se crece...

\section{Correspondencia:}

\section{Luis Jaime Cisneros}

Miembro de Número de la Academia Peruana de la Lengua.

Correo electrónico: academiaperuanadelalengua@yahoo.com

luis.jaime.cisneros@academiaperuanadelalengua.org 